\title{
PERUBAHAN pH , KEASAMAN DAN INDEKS FERMENTASI BIJI KAKAO SELAMA FERMENTASI HASIL BIJI KAKAO (THEOBROMA CACAO)
}

\author{
Dr. Mulono Apriyanto, S.TP., MP \\ Dosen Teknologi Pangan UNISI \\ mulonoapriyanto71@gmail.com
}

\begin{abstract}
Abstrak
Most cocoa beans are produced by farmers Indonesia is dry cocoa drying whose quality can be improved by the fermentation method, but it takes more optimization for fermentation can run well. This study aimed to determine changes in the chemical properties of fermented dry cocoa beans drying. Dry beans drying is obtained by drying the wet cocoa beans (fresh) in a cabinet dryer with a previously conditioned at a temperature such as drying in the sun, and each determined the reduction of sugar levels. Experiments fermented dry cocoa beans are fermented in the fermentation container with the amount of 100 grams of seed per container. Before the first fermented dry cocoa beans drying on rehydration to obtain a moisture content approaching fresh beans, dry beans drying then incubated for six days and without inverted during fermentation. Each treatment was repeated three times and observed every 24 hours to 120 hours. Reduction sugar, acid levels tertitrasi, the population of yeasts and acetic acid bacteria in fermented pulp was observed during the fermentation process. To determine the quality of dry beans drying measurement of $\mathrm{pH}$ and the fermentation index during fermentation.
\end{abstract}

Keywords : fermentation, dyring in the sun. cocoa beans, pulp cocoa beans, fermentation indexs, sugar

\section{PENDAHULUAN}

Pasca panen penanganan biji kakao segar di tingkat petani dengan dua cara: produksi biji kakao kering difermentasi dan dikeringkan biji kakao kering di bawah sinar matahari tanpa fermentasi. Menurut Biro Pengumpulan Data Statistik (Anonim, 2013) bahwa produksi kakao kering pada tahun 2013 mencapai 5,45 juta ton dan \pm biji kakao kering yang tidak difermentasi \pm 38,5000 ton. Kacang biji kakao kering yang tidak difermentasi terdiri dari pengeringan biji kakao kering (petani produksi) dan biji kakao kering setengah fermentasi. Sebanyak 93\% kakao
Indonesia dihasilkan oleh petani yang mengolah biji kakao hanya dengan cara mencuci dan mengeringkan sinar matahari tanpa melalui proses fermentasi, sedangkan $7 \%$ dihasilkan baik oleh sektor swasta maupun perkebunan nasional dengan proses fermentasi (Anonim , 2013).

Fermentasi kakao pada dasarnya adalah proses reformasi gula dan asam sitrat dalam pulp menjadi asam organik yang dilakukan oleh fermentasi mikroba (Camu, et al., 2008, (Ardhana dan Fleet, 2003), Apriyanto et.al, 2016a, Apriyanto et.al, 2016b, Apriyanto et.al, 2016c, dan Apriyanto, 2017). Asam organik akan menginduksi reaksi enzimatik yaitu pada 
biji, menyebabkan perubahan biokimia yang akan membentuk senyawa yang memberi rasa, rasa, dan warna coklat (Biehl, et.al, 1985, dan Afoakwa, et.al, 2014).

Proses ini dilakukan dengan cara biji kakao pada wadah tertutup selama 57 hari dengan pembalikan yang menyertainya setiap 2 hari. Tanpa melalui proses fermentasi biji kakao akan terasa pahit, astringen, dan tidak akan menghasilkan aroma khas coklat saat diolah (Schwan dan Wheals, 2004, (Apriyanto dan Rujiah, 2017)).

Biji kakao kering telah kehilangan sebagian besar kandungan air dan substratnya. Kandungan air selama fermentasi digunakan dalam reaksi enzimatik pada biji dan pertumbuhan mikroba pada pulp (Schwan and Wheals, 2004). Air akan mempertemukan enzim tersebut ke substrat yang ada di dalam benih sehingga hidrolisis dan oksidasi dari calon senyawa rasa, warna, dan aroma coklat dapat terjadi. Kandungan air yang dibutuhkan dalam fermentasi kakao lebih dari 35\%. Substrat adalah bahan yang dirombak oleh mikroba selama fermentasi. Substrat dalam fermentasi biji kakao adalah gula dan asam sitrat yang terkandung dalam pulp. Proses fermentasi pelaku fermentasi mikroba akan merombak pulp menjadi asam organik. Asam akan menyebar ke dalam biji dan menginduksi reaksi enzimatik untuk membentuk senyawa calon rasa, aroma dan warna (Afoakwa et al., 2014). Berdasarkan hal tersebut di atas perlu dilakukan pengembalian kadar air biji kakao sebelum fermentasi. Penelitian fermentasi biji kakao kering dengan menggunakan non fermentasi berhasil dilakukan di laboratorium teknik PAU, UGM. , Penelitian ini bertujuan untuk mengetahui perubahan sifat kimia pengeringan biji kakao kering fermentasi.

\section{METODOLOGI}

\section{Preparasi biji kakao}

Biji kakao yang digunakan diambil dari biji kakao matang, yaitu buah yang memiliki warna kuning atau oranye dan terdengar cekung saat disadap. buah tanpa dicuci lalu dibelah untuk dilepas biji dan dikeringkan dalam kabinet pengering dengan suhu $40{ }^{\circ} \mathrm{C}$ sampai kadar air biji sampai 15\%. 100 gram kacang kering yang direndam dalam air $60 \mathrm{ml}$ kemudian difermentasi selama 5 hari (120 jam) secara spontan pada suhu kamar dan diperoleh perubahan data total gula, reduksi gula, $\mathrm{pH}$, keasaman, indeks fermentasi dan suksesi mikroba yang terjadi dibandingkan untuk fermentasi biji kakao segar.

\section{Preparasi sampel pulp}

Pulp secara manual dipisahkan dari biji dengan menggosok biji (agar pulp yang menempel) di antara jari dan meremas pulpa menjadi kantong sampel yang bersih.

\section{a. Analisis awal}

Analisis pendahuluan dilakukan untuk mengetahui kadar air dan pengurangan gula pada pulp dan biji kakao yang hilang selama proses pengeringan. Kadar air biji kakao ditentukan dengan menggunakan metode gravimetrik, yang mengurangi kadar gula dari pulp basah, pulp kering menggunakan metode Nelson-Somogy di Sudarmadji et.al. (1997).

\section{b. Biji Kakao Kering}

Pengeringan biji kakao kering fermentasi dilakukan dalam toples kaca dengan jumlah biji kering kering di bawah sinar matahari sebanyak $100 \mathrm{~g} /$ gelas jar. Sebelum difermentasi kering biji kakao pengeringan direhidrasi dengan air suling sebanyak $60 \mathrm{ml}$ dan 
kemudian diinkubasi pada suhu kamar selama 5 hari.

\section{Desain Eksperimental}

Desain eksperimen faktorial $2 \times 3$ digunakan untuk penelitian ini. Faktor utama yang diteliti adalah perlakuan kakao (baru dan sundry) dan waktu fermentasi $(0,3,6$ hari). Keasaman $\mathrm{pH}$, non-volatile (titrasi), pengurangan gula, indeks fermentasi, dipelajari, analisis mikroba.

\section{4. pH dan keasaman non-volatile (titrasi)}

Keasaman $\mathrm{pH}$ dan non-volatile (titrasi) pulp ditentukan dengan menggunakan metode yang dijelaskan oleh Nazaruddin et al. (2006) dengan sedikit modifikasi. Sepuluh gram pulp dihomogenisasi dalam $90 \mathrm{ml}$ air suling panas, diaduk secara manual selama 30 detik dan disaring menggunakan kertas saring Whatman No. 4® dan didinginkan sampai 20-25oC. Dua puluh lima (25) ml aliquot dari filtrat yang dihasilkan disaring ke dalam gelas kimia dan $\mathrm{pH}$ diukur dengan menggunakan meter $\mathrm{pH}$ (model MP230 Mettler Toledo MP 230, Mettler Company Limited, Jenewa, Swiss) dikalibrasi dengan buffer pada $\mathrm{pH}$ 4,01, 7,00 dan 9.21. Sebanyak $10 \mathrm{ml}$ aliquot digunakan untuk menentukan keasaman dengan titrasi sampai $\mathrm{pH}$ titik akhir dengan larutan $0,1 \mathrm{~N} \mathrm{NaOH}$ dan nilai yang dilaporkan sebagai mol natrium hidroksida per $100 \mathrm{~g}$ sampel. Analisis dilakukan dalam rangkap tiga dan nilai rata-rata yang dilaporkan.

\section{Penentuan indeks fermentasi}

Penentuan indeks fermentasi biji kakao ditentukan dengan menggunakan metode yang dijelaskan oleh Misnawi et.al. (2002). Lima ratus miligram bubuk kakao yang dihilangkan lemak ditimbang ke dalam labu berbentuk kerucut $125 \mathrm{ml}$ sebelum campuran $50 \mathrm{ml}$ larutan metanol: asam hidroklorida (97: 3) ditambahkan, campuran didinginkan pada suhu $8 \pm 2{ }^{\circ} \mathrm{C}$ di lemari es selama $16-18$ h. Ekstrak yang jelas diperoleh dengan penyaringan melalui kertas saring Whatman No. 1. Indeks fermentasi dihitung, berdasarkan rasio absorbansi pada $460 \mathrm{~nm}$ terhadap absorbansi pada $530 \mathrm{~nm}$.

\section{HASIL DAN PEMBAHASAN}

\section{Perubahan profil pH biji kakao}

PH biji kakao serba guna dilaporkan berkisar antara 5 - 5,7 dan biji kakao baru dilaporkan berkisar antara 6 - 6.2 (Gambar 1). Selama dua hari pertama fermentasi, $\mathrm{pH}$ mencatat kecenderungan penurunan pada kedua cara fermentasi (SBBL dan SBWL) sebelum sedikit meningkat pada akhir fermentasi. Selama dua hari pertama atau 48 jam fermentasi, tren penurunan secara bertahap untuk biji kakao segar dan biji kakao yang berlebihan sebelum sedikit meningkat pada akhir fermentasi (Gambar 1). Tahap fermentasi awal bersifat asam ( $\mathrm{pH}$ rendah) karena pulp kakao mengandung sejumlah asam sitrat yang menguntungkan ragi untuk tumbuh. Namun saat fermentasi berlangsung, ragi yang dominan dengan aktivitas pektinolitik yang baik menurunkan bubur kertas dan mengeluarkan asam sitrat untuk memungkinkan bakteri berikutnya tumbuh. Hal ini menjelaskan mengapa ada sedikit peningkatan $\mathrm{pH}$ dari 3,8 $\pm 0,10$ (48 jam) menjadi 4,2 \pm 0,20 (72 jam) untuk biji kakao dan 3,6 \pm 0,10 (48 jam) sampai 4,4 \pm 0,20 (98 jam) untuk biji kakao baru hal ini sejalan dengan penelitian Apriyanto et.al (2016a) dan Apriyanto dan Rujiah, (2017).

Begitu lingkungan fermentasi menjadi lebih aerobik, bakteri asam laktat (LAB) akan menengahi fermentasi 
dan mengubah metabolit menengah menjadi asam laktat. Pada tahap terakhir fermentasi, bakteri asam asetat (AAB) mengoksidasi etanol yang dihasilkan oleh yeast dan LAB menjadi asetat dan selanjutnya menjadi karbon dioksida dan air. Namun demikian, asam asetat sangat mudah menguap dan jarang terakumulasi dalam kondisi aerob. Berbeda dengan $\mathrm{pH}$, keasaman titrasi adalah indikator yang lebih tepat untuk mengukur tingkat asam total dalam setiap proses fermentasi dan biasanya kedua parameter berkorelasi negatif. Menurut Lagunes-Galvez dkk. (2007), sintesis asam laktat sangat umum terjadi pada fermentasi asam laktat, terutama fermentasi kakao yang dilakukan pada kondisi anaerob. Suhu meningkat dengan mantap dari 27 sampai 40 (biji kakao segar) dan 26 sampai $38^{\circ} \mathrm{C}$ (biji kakao sundry)), setelah terjadinya fermentasi kakao sejalan dengan penelitian Apriyanto et al, (2016b) dan Apriyanto et al, (2016c).

Kenaikan suhu yang stabil dapat dikaitkan dengan pelepasan panas dari biomassa kakao selama proses berlangsung. Awalnya, ragi adalah spesies dominan yang memanfaatkan substrat yang dapat difermentasi (gula) sebelum mengubahnya menjadi etanol dan selanjutnya menjadi asam asetat melalui suksesi mikroba. Konversi substrat yang dapat difermentasi ke dalam produk samping metabolit yang diinginkan dilakukan secara eksotermik, dan karenanya membantu peningkatan suhu (Apriyanto et al, 2016c).

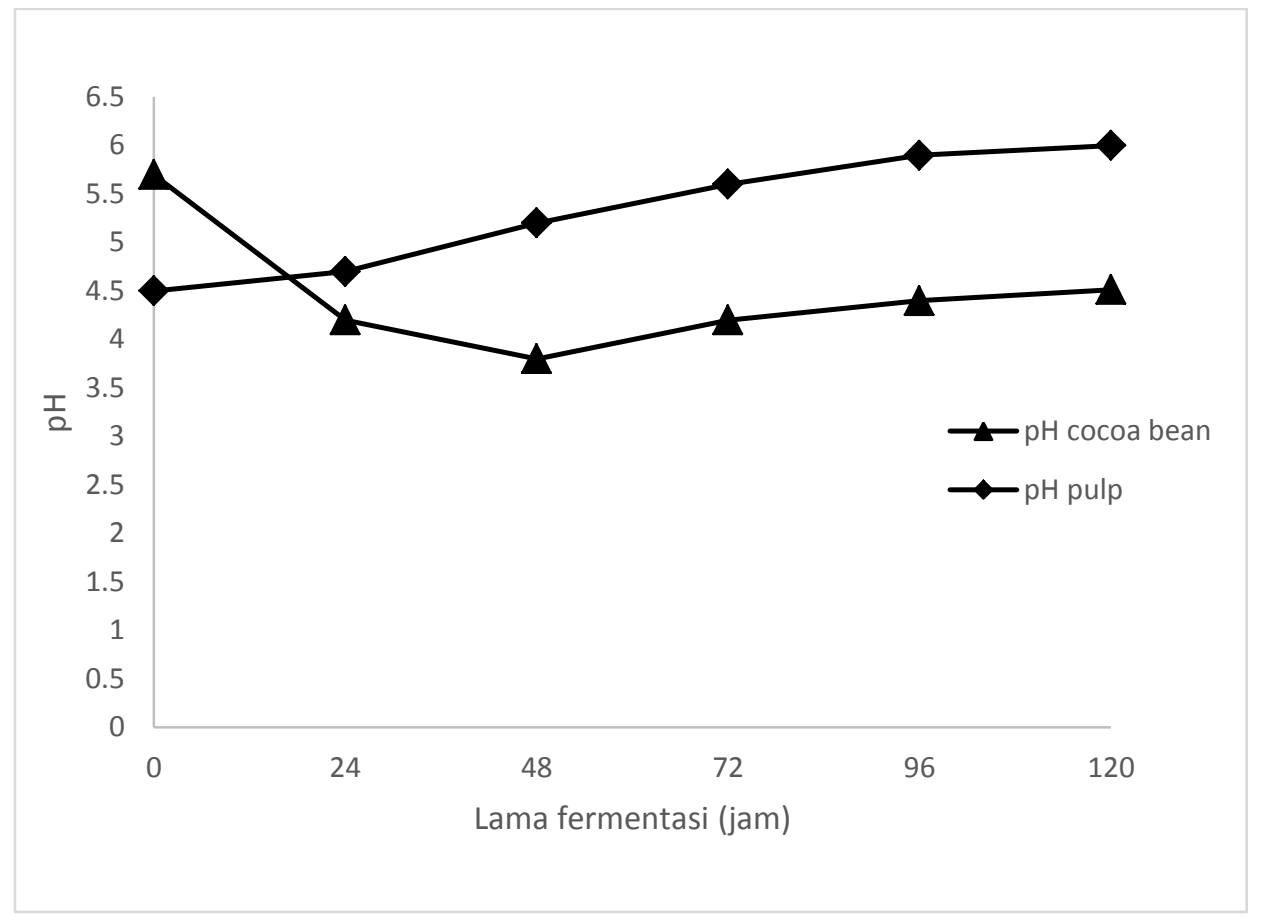

Gambar 1. Perubahan $\mathrm{pH}$ biji kakao selama fermentasi

\section{Perubahan keasaman non-volatile (titrasi) pulp kakao}

Selama fermentasi biji kakao, mikroorganisme merusak gula dalam bubur kertas sehingga menghasilkan alkohol dan asam organik, terutama asam asetat yang kemudian menyebar ke dalam buncis. Produksi asam dalam pulp penting dalam fermentasi kakao karena 
asam ini berdifusi ke dalam biji dan selanjutnya menginduksi reaksi biokimia penting yang menyebabkan biji kakao yang difermentasi dengan baik. Tingkat keasaman paling tinggi pada 48 jam fermentasi karena mayoritas gula pulp mungkin terdegradasi menjadi alkohol yang kemudian dioksidasi menjadi asam asetat oleh bakteri asam asetat dalam waktu 48 jam setelah fermentasi. Ardana dan Fleet (2003), Apriyanto et al, (2016a) melaporkan konsentrasi tinggi $10 \mathrm{mg} / \mathrm{g}$ asam asetat pada pulp coklat pada 72 jam (3 hari) fermentasi.

Tingkat keasaman menurun setelah hari ke 3 fermentasi karena pada saat itu, sebagian besar asam yang dihasilkan menyebar ke dalam kacang. Sekali lagi, karena volume pulp berkurang, terjadi peningkatan aerasi dalam massa fermentasi yang menyebabkan penguapan asam volatil seperti asam asetat.
Fermentasi menyebabkan kenaikan tingkat keasaman yang signifikan pada biji kakao mencapai maksimum 48 jam fermentasi setelah mana keasaman titrasi menurun sampai akhir fermentasi, dan ini dicatat pada semua perlakuan biji kakao (Gambar 2) . Interaksi antara waktu fermentasi dan persiapan biji kakao berpengaruh nyata $(\mathrm{p}<0,05)$ terhadap tingkat keasaman pulp. Ini mungkin karena fakta bahwa mengurangi volume pulp per biji, mengurangi kadar gula pulpa dan dengan demikian meningkatkan aerasi mikro di dalam pulp. Hal ini menurunkan gula yang dimetabolisme oleh ragi selama fermentasi berikutnya dan akhirnya mengurangi fermentasi alkohol dan pembentukan asam asetat dalam pulp (Apriyanto et al., 2017). Ini menunjukkan prakondisi biji kakao dapat digunakan secara efektif untuk mengurangi tingkat keasaman pada biji kakao selama fermentasi.

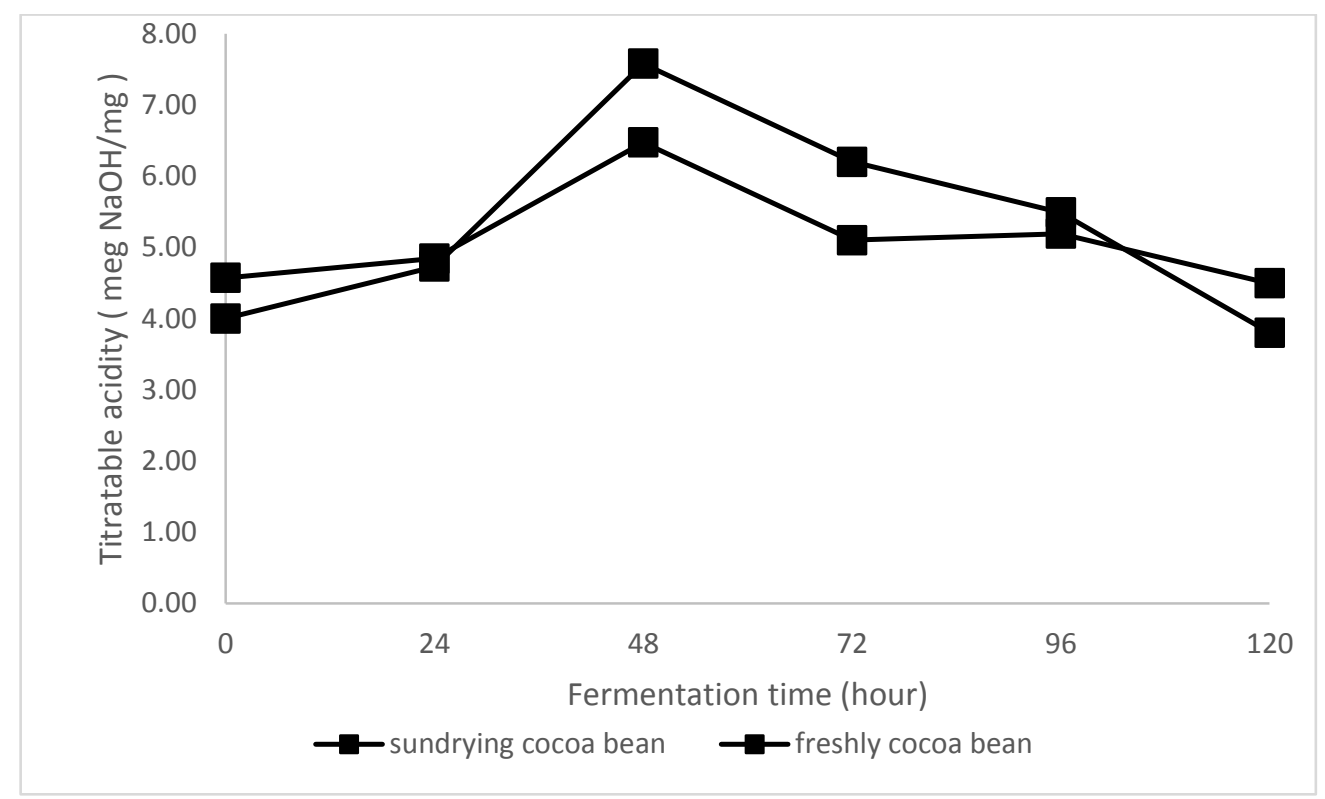

Gambar 2. Perubahan keasaman biji kakao selama fermentasi

\section{Indeks fermentasi}

Indeks fermentasi adalah indeks yang membandingkan absorbansi pada panjang gelombang $460 \mathrm{~nm}$ dan panjang gelombang $540 \mathrm{~nm}$. Jika itu fermentasi yang baik, fermentasi dari indeks yang dihasilkan mendekati 1. Biji kakao 
kering fermentasi kering di bawah sinar matahari dan biji kakao segar disajikan pada Gambar 3.

Angka tersebut menunjukkan bahwa sampai akhir indeks fermentasi biji kering fermentasi untuk pengeringan tidak terpenuhi, hal ini diduga karena suhu fermentasi tidak tercapai. Suhu fermentasi tidak tercapai karena mikroba yang membantu fermentasi dalam jumlah kurang.

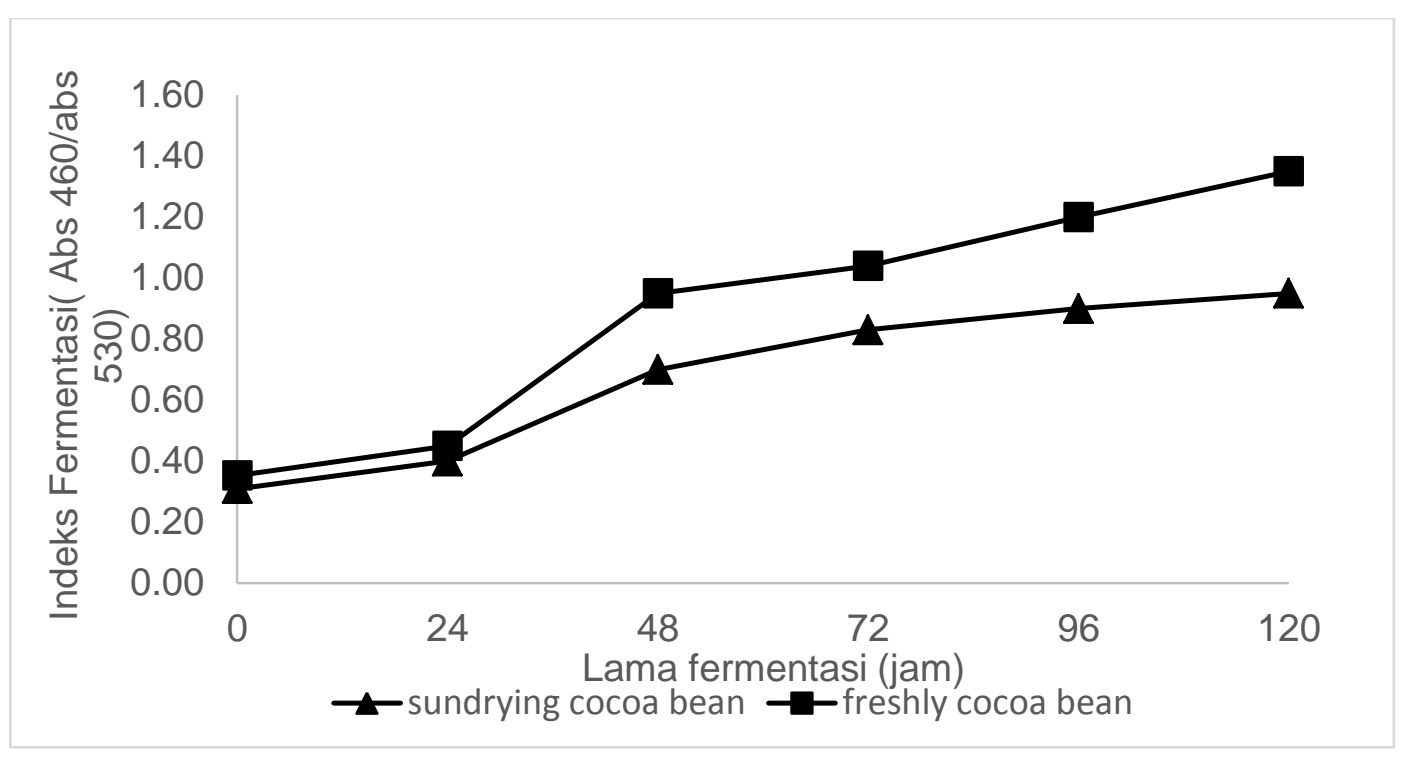

Gambar 3. Biji kakao kering dan biji kakao segar

\section{KESIMPULAN}

Dari hasil penelitian ini disimpulkan bahwa selama pengeringan mikroba tidak sekarat, maka saat direhidrasi. Hal ini dapat dilihat pada suksesi mikroba yang terjadi pada populasi ragi, bal, bakteri asam asetat selama fermentasi. Kualitas pengeringan biji kakao kering fermentasi bila dibandingkan dengan biji kakao fermentasi segar memiliki kesamaan. Indeks hasil fermentasi biji kakao kering pengeringan yang tertinggi adalah 0,95 . Dari keseluruhan data kualitas fermentasi dapat dikatakan bahwa kualitas pengeringan biji kakao kering dapat ditingkatkan melalui fermentasi. Untuk mempercepat proses fermentasi dapat dilakukan penambahan inokulum agar bisa mendapatkan indeks fermentasi yang baik.

\section{DAFTAR PUSTAKA}

Afoakwa, E. O., Budu, A. S., Mensahbrown, H., dan Felix, J. (2014). Changes in Biochemical and Physico-chemical Qualities during Drying of Pulp Preconditioned and Fermented Cocoa ( Theobroma cacao ) Beans. Internasional Food Research Journal.

Afoakwa, Emmanuel Ohene., Kongor, J.E., Takrama, J. Badudu, A. S. (2013). Changes in nib acidification and biochemical composition during fermentation of pulp pre-conditioned cocoa ( Theobroma cacao ) beans. Internasional Food Research Journal, 20(4), 1843-1853.

Anonim. (2013). Produksi Perkebunan Besar menurut Jenis Tanaman, Indonesia. Http://www.bps.go.id. Diakses Tanggal 29/03/014. 
Apriyanto M, Sutardi, Supriyanto dan Eni Harmayani, 2016a. Study on effect of fermentation to the quality parameter of cocoa bean in Indonesia, Asian J. Dairy \& Food Res., 35 (2) 2016 : 160-163.

Apriyanto M, Sutardi, Eni Harmayani dan Supriyanto, 2016b, Perbaikan Proses Fermentasi Biji Kakao Non Fermentasi dengan Penambahan Biakan Murni Saccharomyces cerevisiae, Lactobacillus lactis, dan Acetobacter aceti, AGRITECH, Vol. 36, No. 4, hal 410-415.

Apriyanto M, 2016c. Changes in Chemical Properties of Dreid Cocoa (Theobroma cacao) Beans during Fermentation, Intl. J. Food. Ferment. 5(1): 11-16

Apriyanto M dan Rujiah, 2017. Penurunan total polifenol, etanol, asam laktat, asam asetat, dan asam amino selama fermentasi biji kakao asalan dengan penambahan inokulum. Jurnal Gizi dan Dietetik Indonesia Vol. 5, No. 1 hal 1-8

Ardhana, M., dan Fleet, G. (2003). The microbial ecology of cocoa bean fermentations in Indonesia. International Journal of Food Microbiology, 86(1-2), 87-99. http://doi.org/10.1016/S01681605(03)00081-3

Biehl, B., Brunner, E., Passern, D., Quesnelh, V. C., \& Adomako, D. (1985). Acidification , Proteolysis and Flavour Potential in Fermenting Cocoa Beans, 583598.

Camu, NicholasCamu, N., Winter, T. De, Addo, S. K., Takrama, J. S., Bernaert, H., \& Vuyst, L. De. (2008). Fermentation of cocoa beans: influence of microbial activities and polyphenol concentrations on the flavour of chocolate, 2297(May), 2288-2297. http://doi.org/10.1002/jsfa, Winter, T. De, Addo, S. K., Takrama, J. S., Bernaert, H., \& Vuyst, L. De. (2008). Fermentation of cocoa beans: influence of microbial activities and polyphenol concentrations on the flavour of chocolate, 2297(May), 2288-2297. http://doi.org/10.1002/jsfa

Erna, M., dan Setyani, S. (2008). Pengaruh penambahan inokulum campuran terhadap perubahan kimia dan mikrobiologi selama fermentasi coklat, 13(2), 73-84.

Moreira, I. M. D. V., Miguel, M. G. D. C. P., Duarte, W. F., Dias, D. R., dan Schwan, R. F. (2013). Microbial succession and the dynamics of metabolites and sugars during the fermentation of three different cocoa (Theobroma cacao L.) hybrids. Food Research International, 54(1), 9-17. http://doi.org/10.1016/j.foodres.20 13.06.001

Nazaruddin, R., Seng, L. K., Hassan, O., dan Said, M. (2006). Effect of pulp preconditioning on the content of polyphenols in cocoa beans (Theobroma Cacao) during fermentation. Industrial Crops and Products, 24(1), 87-94. http://doi.org/10.1016/j.indcrop.20 06.03.013

Schwan, R. F., dan Wheals, A. E. (2004). The microbiology of cocoa fermentation and its role in chocolate quality. Critical Reviews in Food Science and Nutrition, 44(4), 205-221. http://doi.org/10.1080/1040869049 0464104. 